\title{
Achieving sustainability in solving the electronic waste (e-waste) problem
}

\author{
Herat S. 龱
}

Received:18.05.2020

Revised: 03.07.2020

Accepted:15.07.2020

\begin{abstract}
Waste from used electrical and electronic equipment, commonly known as e-waste, is growing at a higher rate than the regular municipal waste streams. Global generation of e-waste in 2019 was 53.6 million tonnes. Rising demand for high technology products and their early obsolescence coupled with lack of proper end-of-life management options have all led to unsustainable management of e-waste in many countries. Recycling, design for environment, extended producer responsibility and public-private partnerships (PPPs) are some of the practices attempted by many countries to achieve sustainability in solving the e-waste problem. This paper provides an overview of the practices mentioned above.
\end{abstract}

Key Words: Design for environment, E-waste, Extended producer responsibility, Health impacts, Public-privatepartnerships, Sustainability

\section{Introduction}

The waste from electrical and electronic equipment (EEE), commonly referred to as e-waste or WEEE, is growing fast in the world with a generation of 53.6 million tonnes in 2019 and projected to grow to 74.7 million tonnes by 2030 (Forti et al., 2020). The modern world heavily depends on EEE to drive the high technology sector, critical for many countries' economic development. The benefits of the high technology sector are well known. However, the environmental and health impacts of poor management of end-of-life EEE are relatively unknown. The issue is compounded by the fact that the average life span of many EEEs is reducing by the day due to the availability of products with increased memory, processing power, and attractive design features. This has led to the early obsolescence of many EEEs, causing a significant increase in e-waste generation. Many countries are grappling with the options to manage this challenging waste stream, which consists of several toxic compounds and valuable ones. This paper aims to provide an overview of some initiatives attempted by many countries to move towards proper management of e-waste.

\section{Author's Address}

School of Engineering and Built Environment, Nathan Campus, Griffith University, Queensland 4111, Australia. E-mail.: s.herat@griffith.edu.au

\section{Electronic and electrical industry and} generation of e-waste

E-waste comprises many EEE and its accessories used EEE with an electronic circuit or EEE which utilises electrical power or battery power. Table 1 describes some of the commonly used items. The determination of correct data related to e-waste generation in a particular country is a difficult task. This is because some of the used EEEs do not enter the end-of-life management processes as they are stored by the households. Therefore, most estimates are based on manufacturing or sales data or by estimating the products' lifespan. One of the most recent and comprehensive analyses and estimation of e-waste generated around the world was conducted by Forti et al. (2020). According to this study, the global total e-waste generation in 2019 was 53.6 million metric tonnes (Mt). The Asian region generated the most substantial quantity of e-waste $(24.9 \mathrm{Mt})$, followed by the American region (13.1 Mt), Europe region $(12 \mathrm{Mt})$, Africa $(2.9 \mathrm{Mt})$, and Oceania $(0.7 \mathrm{Mt})$. Furthermore, Forti et al. (2020) has estimated that within the Asian region, China generated the largest amount of e-waste (10.1 Mt), followed by India (3.2 Mt) and Japan $(2.5 \mathrm{Mt})$. Table 2 summaries the ewaste generated in selected countries around the world. In general, EEE comprises different metals and chemical compounds, many of which are toxic to human health and the environment. 
Herat S.

Table 1. Classification of e-waste

\begin{tabular}{|l|l|}
\hline \multicolumn{1}{|c|}{ Category } & \multicolumn{1}{c|}{ Items } \\
\hline Thermal products & Refrigerators, air conditioners, freezers \\
\hline Monitors and Screens & Televisions, laptops, notebooks, monitors, tablets \\
\hline Lamps & Light bulbs, fluorescent bulbs, \\
\hline Heavy items & $\begin{array}{l}\text { Washing machines, dryers, dishwashing machines, PV panels, } \\
\text { photocopiers, electric stoves }\end{array}$ \\
\hline Small items & $\begin{array}{l}\text { Microwaves, electric kettles, video cameras, calculators, toys, } \\
\text { electrical tools, small medical devices, toasters, shavers, } \\
\text { hairdryers, scales, many small electrical and electronic items } \\
\text { used in the kitchen }\end{array}$ \\
\hline Small high technology equipment & $\begin{array}{l}\text { Mobile phones, personal computers, printers, telephones, } \\
\text { routers }\end{array}$ \\
\hline
\end{tabular}

Table 2. E-waste in selected countries

\begin{tabular}{|c|c|c|}
\hline Country & E-waste (tonnes/year) & $\begin{array}{c}\text { E-waste } \\
\text { (kg/person) }\end{array}$ \\
\hline Argentina & 465,000 & 10.3 \\
\hline Australia & 554,000 & 21.7 \\
\hline Brazil & $2,143,000$ & 10.2 \\
\hline Canada & 757,000 & 20.2 \\
\hline China & $10,129,000$ & 7.2 \\
\hline Hong Kong & 153,000 & 20.2 \\
\hline France & $1,362,000$ & 21.0 \\
\hline Germany & $1,607,000$ & 19.4 \\
\hline India & $3,230,000$ & 2.4 \\
\hline Indonesia & $1,618,000$ & 6.1 \\
\hline Japan & $2,569,000$ & 20.4 \\
\hline Nigeria & 461,000 & 2.3 \\
\hline Republic of Korea & 818,000 & 15.8 \\
\hline Russian Federation & $1,631,000$ & 11.3 \\
\hline Saudi Arabia & 595,000 & 17.6 \\
\hline Singapore & 113,000 & 19.9 \\
\hline United Kingdom & $1,598,000$ & 23.9 \\
\hline United States of America & $6,918,000$ & 21.0 \\
\hline
\end{tabular}

When these toxic materials are intact with the EEE, Although in 2003, the European Union banned the they do not cause harm to humans or the manufacturing of EEE containing these toxic environment. However, when EEE is dismantled mental and compound through their Restrictions of during their end-of-life processes such as recycling, Hazardous Substances (RoHS) Directive, there is a these compounds become exposed to the considerable backlog of used and old EEE in homes environment. Poor recycling practices adopted by and offices awaiting disposal. The environmental many countries result in severe human health and sound management (ESM) of e-waste has also environmental impacts. Generally, EEE contains become a significant challenge to many countries toxic metals such as $(\mathrm{Pb})$, mercury $(\mathrm{Hg})$, cadmium due to the widespread transboundary movement of $(\mathrm{Cd})$, chromium $(\mathrm{Cr})$, polybrominated biphenyls used EEE in the name of recycling or final disposal. (PBBs), polybrominated diphenyl ethers (PBDEs), A significant amount of e-waste and used EEE are which are also knowns as flame retardants. transferred from industrialised countries to 
developing countries for end-of-life processes. Unfortunately, moste-waste processing facilities in developing countries do not have the technical skills to operate in an environmentally sound manner due to the heavy involvement of the informal waste recycling sector. Poor extraction of metals, open burning, and other rudimentary practices are causing significant impacts on human health and the environment.

\section{Human health and environmental impacts of e- waste recycling}

The human health and environmental impacts of ewaste recycling have been well studied by researchers around the world, in particular, in countries where e-waste recycling is predominantly undertaken by the informal sector. This section describes some of these studies conducted to highlight the human impacts and environmental effects caused by informal e-waste recycling. Ackah et al. (2019) studied the effects of trace elements in e-waste on the topsoil and subsoil of ewaste recycling sites in Accra, Ghana. They found metal concentrations in Agbogbloshie site (one of the largest informal e-waste recycling sites in the world) exceeded the Dutch Soil Intervention values by $72 \%(\mathrm{Cu}), 57 \%(\mathrm{Zn}), 57 \%(\mathrm{~Pb}), 38 \%(\mathrm{Ba}), 16 \%$
(Cd) and 2\% (As) meaning significant metal contamination in the site. They also found substantial $\mathrm{Pb}$ contamination in open burning and dismantling areas of the site, causing significant carcinogenic risks to people living nearby. A similar study conducted at a major e-waste umpsite in Lagos, Nigeria (Alabi et al., 2020) found an increase in $\mathrm{Pb}$ blood levels of teenage scavenging the site with a range from 2.84 to $189.44 \mu \mathrm{g} / \mathrm{L}$ compared to the control group range 0.01 to 4.21 $\mu \mathrm{g} / \mathrm{L}$. A study conducted by Alam et al. (2019) to assess the genotoxicity of e-waste leachates an ewaste dumpsite in Metro Manila, Philippines showed the heavy presence of $\mathrm{Cd}, \mathrm{Cu}, \mathrm{Ni}, \mathrm{Pb}$ and $\mathrm{Zn}$ in the soil samples of the e-waste recycling sites and the hair of the informal recyclers. Cai et al. (2019) investigated the effect of lead exposure on child sensory integration by correlating the blood levels of children with sensory processing measures living close to e-waste recycling town in China (Guiyu). They concluded that $\mathrm{Pb}$ exposure in ewaste recycling areas might impact the serum cortisol levels and an increase in the difficulty of child sensory integrations, further confirming the impacts on humans, especially young children. Tables 3, 4, and 5 summarises selected studies conducted on the effects of e-waste recycling on human health and the environment.

Table 3. Selected studies on impacts on sediments around recycling sites

\begin{tabular}{|c|c|}
\hline Contaminants and study area & Reference \\
\hline $\begin{array}{l}\text { Investigation of polycyclic aromatic hydrocarbons (PAHs)in soil near an informal e- } \\
\text { waste facility in China }\end{array}$ & Gu et al., 2019 \\
\hline $\begin{array}{l}\text { Study into soil pollution caused by metals from e-waste recycling activities Pearl River } \\
\text { Delta }\end{array}$ & He et al., 2017 \\
\hline Contamination of soils by PAHs near informal e-waste recycling area in Vietnam & Hoa et al., 2020 \\
\hline $\begin{array}{l}\text { Distribution of heavy metals in the soils near an informal e-waste recycling facility in } \\
\text { Nigeria }\end{array}$ & Isimekhai et al., 2017 \\
\hline Contamination of soil by heavy metals generated from a Nigerian e-waste site & Jiang et al., 2019 \\
\hline $\begin{array}{l}\text { Changes in the microbe structure in sediments from rivers near e-waste recycling } \\
\text { facilities in China }\end{array}$ & Liu et al., 2018 \\
\hline $\begin{array}{l}\text { Determination of PBDEs in soils and river sediments near an e-waste recycling facility } \\
\text { in Vietnam }\end{array}$ & Matsukami et al., 2017 \\
\hline $\begin{array}{l}\text { Study into impact from PAHs, PBDEs, and PCBs on the sediments near e-waste } \\
\text { recycling site in Ghana }\end{array}$ & Moeckel et al., 2020 \\
\hline Impact of chlorobenzenes and PCBs in soils from an e-waste recycling area in Vietnam & Nishimura et al., 2018 \\
\hline $\begin{array}{l}\text { Investigation of chlorinated and brominated PAHs in soils resulting from open burning } \\
\text { of e-waste }\end{array}$ & Nishimura et al., 2017 \\
\hline
\end{tabular}


Herat S.

Table 4. Selected studies on human health impacts

\begin{tabular}{|l|l|}
\hline Human health impacts and the study area & Reference \\
\hline $\begin{array}{l}\text { Impact of health on people living near e-waste recycling activities at Agbogbloshie } \\
\text { dumpsite, Ghana }\end{array}$ & Adusi et al., 2020 \\
\hline $\begin{array}{l}\text { Health impacts due to organic compounds from e-waste recycling in developing } \\
\text { countries }\end{array}$ & Awere et al., 2020 \\
\hline $\begin{array}{l}\text { Exposure through inhalation of particulate matter due to open burning of e-waste in } \\
\text { Thailand }\end{array}$ & Bungadaeng et al., 2019 \\
\hline Human health and injuries among e-waste recycling workers in Ghana & Burns et al., 2019 \\
\hline Generation of dioxin-like compounds in e-waste recycling areas & Dai et al., 2020 \\
\hline $\begin{array}{l}\text { Study into the association between open burning of e-waste and childhood lymphoma } \\
\text { in the West Bank, Palestine }\end{array}$ & Davis and Garb, 2019 \\
\hline Determination of mercury levels in the urine of workers in e-waste shops in Thailand & Decharat, 2018 \\
\hline Generation and exposure of PBDEs in a modern e-waste dismantling facility in China & Die et al., 2019 \\
\hline $\begin{array}{l}\text { Study into human health impacts from air pollution resulting from open burning of e- } \\
\text { waste in India }\end{array}$ & Gangwar et al., 2019 \\
\hline $\begin{array}{l}\text { Disruption of thyroid hormone-regulated proteins in residents living near an e-waste } \\
\text { recycling site from PAHs, and PBDEs }\end{array}$ & Guo et al., 2019 \\
\hline $\begin{array}{l}\text { The correlation of maternal urinary metabolites of PAHs and adverse birth outcomes } \\
\text { of people living near an e-waste recycling area }\end{array}$ & Huo et al., 2019 \\
\hline $\begin{array}{l}\text { Concentration of heavy metals in pregnant women and new born children resulting } \\
\text { from informal e-waste recyclingin China }\end{array}$ & Kim et al., 2019 \\
\hline $\begin{array}{l}\text { Impacts of birth outcomes connected with maternal exposure of heavy metals from } \\
\text { informal e-waste recycling in China }\end{array}$ & Kim et al., 2020 \\
\hline
\end{tabular}

Table 5. Studies on impacts on biota.

\begin{tabular}{|l|l|}
\hline Impacts on biota and the study area & Reference \\
\hline $\begin{array}{l}\text { Study in polychlorinated biphenyls in settled dust from informal e-waste recycling in } \\
\text { India }\end{array}$ & Chakraborty et al., 2016 \\
\hline $\begin{array}{l}\text { Concentration of flame retardants and organophosphate esters in the environment } \\
\text { near e-waste recycling facilities }\end{array}$ & Gravel et al., 2019 \\
\hline Determination of chlorinated paraffins in aquatic organisms near an e-waste site & Guan et al., 2020 \\
\hline $\begin{array}{l}\text { Environmental impacts and human exposure to flame retardants from e-waste } \\
\text { recycling in Pakistan }\end{array}$ & Iqbal et al., 2017 \\
\hline Determination of PCBs near an e-waste recycling facility in North-Rhine Westphalia & Klees et al., 2017 \\
\hline
\end{tabular}

\section{Formal e-waste recycling}

Recycling is widely recognised as one of the most popular options for end-of-life management of ewaste. Many countries are starting to realise that although e-waste contains many toxic metals and chemical compounds, they also provide valuable metals that have value in the secondary resource market. This has resulted in many industrialised countries investing funds to develop formal e-waste recycling facilities adopting advanced technologies. Unfortunately, even with such formal facilities, many industrialised countries have achieved a low recycling rate for many reasons. The challenge for e-waste recycling enterprises is to gain access to ewaste for processing. Many households tend to store their used EEE at home, hoping that they will increase value in the future. Due to this fact, many used EEEs are not entering formal e-waste recycling paths. Another issue is most of the ewaste collected by recycling companies in developed countries finally end up in recycling facilities in developing countries. In comparison to industrialised countries, e-waste recycling in developing and emerging economies is predominantly undertaken by the informal sector. However, lately, there has been some movement of

Environment Conservation Journal 
formal e-waste recycling facilities in these regions. The formal e-waste recycling facilities in developing and emerging economies encounter stiff competition for e-waste from the well-established informal e-waste processors.

\section{Formal e-waste recycling - Example 1}

E-Parisaraa Pvt. Ltd (http://ewasteindia.com/)

The company aims to reduce the e-waste being disposed of in landfills or partly recycled by the informal sector that has poor operational processes. E-Parisaraa has the objective of converting e-waste into beneficial resources using environmentally friendly, locally appropriate technologies. These processes are capable of dismantling toner cartridges, recovery of gold from printed circuit boards, recovery of silver from silver-coated components, and shredding printed circuit boards for further processing in Umicore precious metal refining company in Belgium.

\section{Formal e-waste recycling - Example 2}

Terrapro (http://terrapro.in/)

Terrapro was set up as the first PRO to provide services for the manufacturers of EEE to take responsibility for their end-of-life products. According to the E-waste Management Rules 2016 in India, the manufacturers must fulfill several obligations under the EPR scheme. Terrapro provides a total solution to the manufactures by assisting them with plans to achieve specific goals required under the regulations and the preparation of EPR reporting paperwork.

\section{Formal e-waste recycling - Example 3}

Attero Recycling (http://www.attero.in/)

Attero is a metal extraction and e-waste refurbishing facility in India with establishments in several cities. E-waste to the company mainly comes from the informal waste recycling sector and major manufacturers. The company takes away the printed circuit boards from the informal waste collectors by providing a higher price, thereby avoiding the potential environmental and health benefits. The company has developed a comprehensive e-commerce platform to facilitate the sale of refurbished electronics to customers.

\section{Design for Environment (DfE)}

Design for Environment (DfE), commonly referred to as Eco-design, investigates the entire life cycle of a project (from raw material extraction to final disposal) to determine the environmental impacts at each stage and propose changes to product design to minimise those impacts. Such a process involves designing products for practices such as design for energy efficiency, design for re-use, remanufacture, disassembly and recycling, and design for resource conservation. The rationale behind adopting DfE is due to the fact that environmental impacts from products are continually rising, and $60-80 \%$ of its environmental impactsare determined during the design phase. Given the challenges of environmentally sound recycling of e-waste, it is crucial to adopt DfE practices to move away from end-of-pipe considerations. Towards this, the substitution of toxic raw materials with non-toxic materials, designing EEE for easy disassembly and repair, and designing EEE for energy efficiency to reduce the power consumption could contribute significantly to reduce the environmental footprint of the high technology industry. For example, the industry is now required by many countries to remove $\mathrm{Pb}$ metal from the manufacturing process. $\mathrm{Pb}$ was highly utilised in the soldering process of electronic circuits. The industry has now moved to lead-free soldering.

\section{DfE - Example}

Dell is a multinational company that manufactures computers and related products. Their DfE program is one of the most compressive among computer manufactures. Dell's system incorporates DfE at four different stages: Design and Build, Shipping, Use, and Re-use/recycling. During the design and build stage, Dell ensures that the substances they use for their products do not cause any harm to the environment and human health. For example, Dell has phased out medium chained chlorinated paraffins, certain phthalates, and polycyclic aromatic hydrocarbons in addition to the substances banned under the European Union's Restriction of Hazardous Substances Directive (RoHS). During the shipping stage, Dell ensures the use of sustainable packaging materials, smaller transportation footprints, and the use of recyclable materials. 


\section{Extended Producer Responsibility (EPR)}

The Extended Producer Responsibility (EPR) involves making the producer or importer of a product physically and financially responsible for collection and processing of their products after use. The rationale behind EPR is shifting the administrative, logistical, and financial responsibility from government authorities to the manufacturers or importers of the products. Through this process, it is also expected that manufacturers will take into account the environmental considerations (design for the environment) in their manufacturing process to minimise the end-of-life processing costs. EPR has been implemented in many industrialised countries with great success in dealing with the e-waste problem. The reason for this success is the ability of these countries to keep clear records of original manufacturers or importers. Identifying the manufacturer or importer is a crucial element of a successful EPR system. However, the same cannot be said when it comes to emerging and developing nations. Some of these countries already have EPR systems to deal with the e-waste problem; however, successful implementation has become a major challenge for various reasons. The European Union implemented an EPR system in 2003 to deal with the e-waste problem through its Waste Electrical and Electrical Directive (WEEE Directive). Since then, many countries adopted various forms of EPR, including product take-back schemes, advanced recycling fees, container deposit schemes, etc. Most of these schemes are managed by Producer Responsibility Organisations (PROs), typically appointed by the government to administer the system on their behalf. The manufacturers or importers of EEE pay an annual fee to the PRO-based on their market input. The fee is utilised by the PRO towards the logistics and proper recycling of e-waste through licensed recyclers.

\section{EPR - Example 1}

Samsung Takeback and Recycling (https://www.samsung.com/us/aboutsamsung/sustai nability/environment/responsible-recycling/)

The Samsung takeback and recycling program (STAR) provides free drop-off of Samsung branded products in several locations in Indian cities. They provide fixed drop-off locations for smaller products, such as mobile phones and cameras. For larger items such as televisions, washing machines, and refrigerators, Samsung offers free pick-up service from the customers. The STAR initiative also includes a program to raise awareness among the consumers about the proper recycling of used EEEs.

\section{EPR - Example 2}

Xiaomi (India) (https://karosambhav.com/)

Xiaomi, one of the largest selling mobile phones and smart television brands in India, has developed a nationwide campaign to manage e-waste responsibly. The company has an extensive home pick up service to collect their used products from Indian homes. To expand their services, Xiaomi has partnered with Karo Sambhav, a leading PRO appointed by the Indian government. The customers can also utilise the collection points provided by Karo Sambhav to deposit their used Xiaomi brand products.

\section{Public-private partnerships (PPPs) to manage e- waste}

The public-private partnerships, commonly known as PPPs, form a crucial link in the e-waste management system. While the national governments set the agenda or targets to achieve in solving the e-waste problem, the operational responsibility of the system heavily depends upon the financial and human resource potential of the provincial or the municipal sector. These alone are unable to achieve sound e-waste management systems, thus requiring input from the private sector to build the necessary infrastructure and bring in the technology. The PPPs also benefit the businesses and the community as they can effectively utilise the services provided by the private sector. The private sector can also benefit from expanding its marketing potential and enhancing their productivity.

\section{PPP - Example 1}

Clean e-India Initiative

(http://www.cleaneindia.org/)

The Clean e-India initiative was launched by Attero, which is one of the largest e-waste recycling companies in India. The initiative was implemented to ensure responsible and sustainable collection and recycling of e-waste across the nation. The program 
utilises a services of e-captains who come and visit the households to collect their e-waste from the doorstep. The e-captain transfers the products to the Attero e-waste processing center for responsible recycling.

\section{PPP - Example 2}

E-waste: From Toxic to Green (https://www.chintan-india.org/)

As in many developing countries, informal e-waste recycling sector is very active in India. Although the collection and recycling rate is high, these groups are not aware of the environmental and human health impacts of their operation. To address this issue, the Toxic to Green initiative was launched to train the waste pickers for safe disposal and recycling of e-waste. Chintan, an Indian nongovernmental organisation, has cooperated with the government sector to develop a partnership with a registered association of waste pickers, to train their members on how to collect and handle e-waste in a safe manner.

\section{Conclusion}

E-waste has become a hidden dilemma as it is growing at a faster rate than many other waste streams but with low visibility. The paper highlighted the lack of proper formal infrastructure to process end-of-life EEE, inability to deal with ewaste processing conducted by the informal ewastesector, weak regulatory framework to deal with this emerging waste stream, underdeveloped/poor waste management systems, illegal import of e-waste for recycling, accessing funds towards developing proper e-waste recycling facilities, awareness-raising among the consumers, and effective implementation of EPR systems as key driving challenges for moving towards a sustainable e-waste management system. The paper also found that the private sector can bring in the technology and investment to assist the public sector in dealing with the e-waste problem. However, it would be difficult to attract the private sector towards e-waste management unless the policymakers have created the enabling conditions to ensure they receive economic and business benefits from the processing of e-waste.

\section{References}

Ackah, M. 2019. Soil elemental concentrations, geoaccumulation index, non-carcino risks in functional areas of an informal e-waste recycınng area in Accra, Ghana, Chemosphere, 235: 908-917.

Adusi, A., Arko-Mensah, J., Dzodzomenyo, M., Stephens, J., Amoabeng, A., Waldschmidt, S., Löhndorf, K., Agbeko, K., Takyi, S., Kwarteng, L., Acquah, A., Botwe, P., Tettey, P., Kaifie, A., Felten,M., Kraus, T., Küpper, T. and Fobil, J. 2020. Spatiality in Health: The Distribution of Health Conditions Associated with Electronic Waste Processing Activities at Agbogbloshie, Accra. Annals of global health, 86 (1): 31 .

Alabi, O. A., Adeoluwa, Y. M. and Bakare, A. A. 2020. Elevated Serum $\mathrm{Pb}, \mathrm{Ni}, \mathrm{Cd}$, and $\mathrm{Cr}$ Levels and DNA Damage in Exfoliated Buccal Cells of Teenage Scavengers at a Major Electronic Waste Dumpsite in Lagos, Nigeria. Biological Trace Element Research, 194 (1): 24-33.

Alam, Z. F., Riego, A. J. V., Samson, J. H. R .P. and Valdez, S. A. V. 2019. The assessment of the genotoxicity of e-waste leachates from e-waste dumpsites in Metro Manila, Philippines. International Journal of Environmental Science and Technology, 16 (2): 737-754.

Awere, E., Obeng, P. A., Bonoli, A. and Obeng, P. A. 2020. Ewaste recycling and public exposure to organic compounds in developing countries: a review of recycling practices and toxicity levels in Ghana. Environmental Technology Reviews, 9 (1): 1-19.

Baldé, C. P., Wang, F., Kuehr, R. and Huisman, J. 2014. The Global E-waste Monitor - 2014, United Nations University, IAS-SCYCLE, Bonn, Germany. http://i.unu.edu/media/unu.edu/news/52624/UNU-1st Global- E- Waste-Monitor-2014-small.pdf

Bungadaeng, S., Prueksasit, T. and Siriwong, W. 2019. Inhalation exposure to respirable particulate matter among workers in relation to their e-waste open burning activities in Buriram Province, Thailand. Sustainable Environment Research, 1 (1), art. no. 26

Burns, K. N., Sayler, S. K. and Neitzel, R. L. 2019. Stress, health, noise exposures, and injuries among electronic waste recycling workers in Ghana, Journal of Occupational Medicine and Toxicology, 14 (1), art. no. 1

Cai, H., Xu, X., Zhang, Y., Cong, X., Lu, X. and Huo, X. 2019. Elevated lead levels from e-waste exposure are linked to sensory integration difficulties in preschool children. NeuroToxicology, 71: 150-158.

Chakraborty, P., Prithiviraj, B., Selvaraj, S. and Kumar, B. 2016. Polychlorinated biphenyls in settled dust from informal electronic waste recycling workshops and nearby highways in urban centers and suburban industrial 
Herat $\mathbf{S}$.

roadsides of Chennai city, India: Levels, congener profiles and exposure assessment. Science of the Total Environment, 573: 1413-1421.

Dai, Q., Xu, X., Eskenazi, B., Asante, K. A., Chen, A., Fobil, J., Bergman, Å., Brennan, L., Sly, P. D., Nnorom, I. C., Pascale, A., Wang, Q., Zeng, E. Y., Zeng, Z., Landrigan, P. J., Bruné Drisse, M.. N. and Huo, X. 2020. Severe dioxinlike compound (DLC) contamination in e-waste recycling areas: An under-recognized threat to local health, Environment International, 139, art. no. 105731

Davis, J. M. and Garb, Y. 2019. A strong spatial association between e-waste burn sites and childhood lymphoma in the West Bank, Palestine. International Journal of Cancer, 144 (3): 470-474.

Decharat, S. 2018. Urinary mercury levels among workers in ewaste shops in Nakhon Si Thammarat Province, Thailand. Journal of Preventive Medicine and Public Health, 51 (4): 196-204.

Die, Q., Nie, Z., Huang, Q., Yang, Y., Fang., Y., Yang, J. and He, J. 2019. Concentrations and occupational exposure assessment of polybrominated diphenyl ethers in modern Chinese e-waste dismantling workshops. Chemosphere, 214: $379-388$

Forti, V., Balde, C. P., Kuehr, R. and Bel, G. 2020. The Global E-waste Monitor. Quantities, flows and the circular economy potential. United Nations University (UNU)/United Nations Institute for Training and Research (UNITAR) - co-hosted SCYCLE Programme, International Telecommunication Union (ITU) \& International Solid Waste Association (ISWA), Bonn/Geneva/Rotterdam

Gangwar, C., Choudhari, R., Chauhan, A., Kumar, A., Singh, A., Tripathi, A. 2019. Assessment of air pollution caused by illegal e-waste burning to evaluate the human health risk. Environment International, 125: 191-199.

Gravel, S., Lavoué, J., Bakhiyi, B., Diamond, M. L., Jantunen, L. M., Lavoie, J. and Labrèche, F. 2019. Halogenated flame retardants and organophosphate esters in the air of electronic waste recycling facilities: Evidence of high concentrations and multiple exposures. Environment international, 128: 244-253.

Gu, W., Bai, J., Yuan, W., Ma, E., Zhang, C. and Wang, J. 2019. Pollution analysis of soil polycyclic aromatic hydrocarbons from informal electronic waste dismantling areas in Xinqiao, China. Waste Management and Research, 37 (4): 394-401

Guan, K. L., Liu, Y., Luo, X. J., Zeng, Y. H. and Mai, B. X. 2020. Short- and medium-chain chlorinated paraffins in aquatic organisms from an e-waste site: Biomagnification and maternal transfer. Science of the Total Environment, 708, art. no. 134840

Guo, L. C., Yu, S., Wu, D., Huang, J., Liu, T., Xiao, J., Huang, W., Gao, Y., Li, X., Zeng, W., Rutherford, S., Ma, W., Zhang, Y. and Lin, L. 2019. Disruption of thyroid hormone regulated proteins and gene expression by polychlorinated biphenyls, polybrominated diphenyl ethers and new flame retardants in residents of an e-waste region. Environmental Pollution, 254, art. no. 112925

He, K., Sun, Z., Hu, Y., Zeng, X., Yu, Z. and Cheng, H. 2017. Comparison of soil heavy metal pollution caused by ewaste recycling activities and traditional industrial operations. Environmental Science and Pollution Research, 24(10): 9387-9398.

Hoa, N. T. Q., Anh, H. Q., Tue, N. M., Trung, N. T., Da, L. N., Van Quy, T., Huong, N. T. A., Suzuki, G., Takahashi, S., Tanabe, S., Thuy, P. C., Dau, P. T., Viet, P. H., Tuyen, L. H. 2020. Soil and sediment contamination by unsubstituted and methylated polycyclic aromatic hydrocarbons in an informal e-waste recycling area, northern Vietnam: Occurrence, source apportionment, and risk Assessment. Science of the Total Environment, 709, art. no. 135852

Huo, X., Wu, Y., Xu, L., Zeng, X., Qin, Q. and Xu, X. 2019. Maternal urinary metabolites of PAHs and its association with adverse birth outcomes in an intensive e-waste recycling area, Environmental Pollution, 245: 453-461.

Iqbal, M., Syed, J. H., Breivik, K., Chaudhry, M. J. I., Li, J., Zhang, G. and Malik, R. N. 2017. E-Waste Driven Pollution in Pakistan: The First Evidence of Environmental and Human Exposure to Flame Retardants (FRs) in Karachi City. Environmental Science, and Technology, 51 (23): 13895-13905.

Isimekhai, K. A., Garelick, H., Watt, J. and Purchase, D. 2017. Heavy metals distribution and risk assessment in soil from an informal E-waste recycling site in Lagos State, Nigeria. Environmental Science and Pollution Research, 24(20): 17206-17219.

Jiang, B., Adebayo, A., Jia, J., Xing, Y., Deng, S., Guo, L., Liang, Y. and Zhang, D. 2019. Impacts of heavy metals and soil properties at a Nigerian e-waste site on soil microbial community. Journal of Hazardous Materials, 362.

Kim, S., Xu, X., Zhang, Y., Zheng, X., Liu, R., Dietrich, K., Reponen, T., Ho, S. M., Xie, C., Sucharew, H., Huo, X. and Chen, A. 2019. Metal concentrations in pregnant women and neonates from informal electronic waste recycling. Journal of Exposure Science and Environmental Epidemiology, 29 (3): 406-415.

Kim, S. S., Xu, X., Zhang, Y., Zheng, X., Liu, R., Dietrich, K. N., Reponen, T., Xie, C., Sucharew, H., Huo, X. and Chen, 
A. 2020. Birth outcomes associated with maternal exposure to metals from informal electronic waste recycling in Guiyu, China. Environment International, 137, art. no. 105580

Klees, M., Hombrecher, K. and Gladtke, D. 2017. Polychlorinated biphenyls in the surrounding of an e-waste recycling facility in North-Rhine Westphalia: Levels in plants and dusts, spatial distribution, homologue pattern and source identification using the combination of plants and wind direction data. Science of the Total Environment, 606-615.

Liu, J., Chen, X., Shu, H. Y., Lin, X. R., Zhou, Q. X., Bramryd, T., Shu, W. S. and Huang, L. N. 2018. Microbial community structure and function in sediments from ewaste contaminated rivers at Guiyu area of China. Environmental Pollution, 235: 171-179.

Matsukami, H., Suzuki, G., Someya, M., Uchida, N., Tue, N. M., Tuyen, L. H., Viet, P. H., Takahashi, S., Tanabe, S. and Takigami, H. 2017. Concentrations of polybrominated diphenyl ethers and alternative flame retardants in surface soils and river sediments from an electronic wasteprocessing area in northern Vietnam, 2012-2014. Chemosphere, 167: 291-299.
Moeckel, C., Breivik, K., Nøst, T. H., Sankoh, A., Jones, K. C. and Sweetman, A. 2020. Soil pollution at a major West African E-waste recycling site: Contamination pathways and implications for potential mitigation strategies. Environment International, 137, art. no. 105563

Nishimura, C., Suzuki, G., Matsukami, H., Agusa, T., Takaoka, M., Takahashi, S., Minh Tue, N., Viet, P. H., Tanabe, S., Takigami, H. and Fujimori, T. 2018. Soil pollution by chlorobenzenes and polychlorinated biphenyls from an electronic waste recycling area in Northern Vietnam. International Journal of Environment and Pollution, 63 (4): 283-297.

Nishimura, C., Horii, Y., Tanaka, S., Asante, K. A., Ballesteros, F., Viet, P. H., Itai, T., Takigami, H.,Tanabe, S. and Fujimori, T. 2017. Occurrence, profiles, and toxic equivalents of chlorinated and brominated polycyclic aromatic hydrocarbons in E-waste open burning soils. Environmental Pollution, 225: 252-260. 